\title{
Cork: sustainability and new applications
}

\author{
Luís Gil * \\ Laboratório Nacional de Energia e Geologia I.P., Lisboa, Portugal \\ *Correspondence: luis.gil@Ineg.pt \\ Edited by: \\ José Alejandro Heredia-Guerrero, Fondazione Istituto Italiano di Tecnologia, Italy \\ Reviewed by: \\ Emanuel Mouta Fernandes, University of Minho, Portugal \\ Marco Caniato, University of Trieste, Italy
}

Keywords: cork, cork-based materials, cork composites, cork applications, cork in construction

Cork is a strategic material used in multiple applications and its use has accompanied mankind since the days of Ancient Egypt. The cork oak forests are extremely well adapted to the semi-arid regions of southern Europe and northern Africa (western Mediterranean). These forests help to prevent the advance of desertification, improve water penetration into the soil and hydrological regulation, promote soil conservation, and being the perfect habitat for many animal and vegetables species. Consequently, these forests promote biodiversity (Pereira, 2007; Gil, 2011, 2014).

Save the cork forests, increasing the area and the quantity and quality of cork produced and develop new products with high added value are essential actions. The loss of the economic importance of the cork activity would lead to an uncertain future of cork oak forests, promoting biodiversity loss, land abandonment (social desertification), and also social imbalance. This could lead to the disappearance of one of the most sustainable industries based on forest products, beyond the environmental and nature problems created.

One of the ways to decrease the amount of carbon dioxide in the atmosphere is the production of long-life products based on plant biomass, which include without doubt, cork products. Furthermore, these materials are "carbon neutral" at the time of decomposition or energy recovery.

A very important aspect has to do with the increase in production due to cork extraction. This is caused by the need of the tree to be rapidly protected from the environment after the removal of its bark. This operation will serve as a stimulus to the production of new suberous material, particularly in the early years after the extraction. During the tree lifetime in operation, an average cork oak produces about four times more cork bark than the cork tree would produce if it were not subject to stripping. The sum of the various layers of cork produced and harvested is greater than the single layer of cork produced if there was no extraction during the life of a tree (Gil, 1998, 2011).

Related to environmental aspects of the transformation of the cork raw material, it can be mentioned the production of expanded cork agglomerate. The manufacture of this cork product only uses superheated steam, using generators fueled with cork waste, not introducing any other products not exclusively cork, and giving up agglomeration based on resins of the cork itself. So, this is a completely natural and ecological product. In addition, in the processing of this and other cork products an important residue is produced, cork powder. This powder is commonly burned to produce steam and/or power used in the factories themselves, given the high energy content of this material. Also, all other industrial cork wastes are reused or valorized in another way (Gil, 1998). So, there is really no wasted cork.

Meanwhile, cork products for the construction industry, are ones of the most suitable for sustainable and efficient energy construction, given its mentioned ecological characteristics. These materials are good thermal insulators, conferring to the buildings good thermal quality and good thermal behavior according to the energy certification systems. In addition, these products contribute to the general comfort and also indoor air quality (Gil, 2007).

In this regard, it should be noted that there are a number of new derivatives products of cork or incorporating new technologies applied to traditional products, which are still in various stages of development. These may have or be adapted for use in construction, one of the most interesting areas of application although several other fields of applications are also under consideration. These are new products that may eventually contribute to a greater sustainability in the construction business and also in the cork sector. A short selection on these new materials that can be foreseen for building applications is as follows.

For example, we can start by addressing a new product derived from cork that is being introduced in the market, consisting of a flexible tubular cork pipe coating obtained by extruding a mixture of granulated cork with a polyurethane resin binder (Esteves, 2010). This product is intended for industrial and residential applications for mechanical, thermal, and acoustic insulation. Its application is foreseen particularly under conditions where the outer wear caused by photo-degradation, chemical, physical, and biological conditions is very heavy, resisting better than competing insulation materials. It is anticipated a widespread use in piping insulation, e.g., in air conditioning and central heating, water heating systems, solar energy and water pipes, etc. This material may also be buried in the ground or embedded in construction.

Another product that is also being developed is a block of concrete with cork, with optimized geometry, light weight and good thermal and acoustic performance, maintaining good physical and mechanical behavior (Branco et al., 2008). This block can be used as a construction element, e.g., 
as a brick. It is also being developed a constructive solution, which is a prefabricated vertical partition element incorporating cork, having a high thermal and acoustic performance. It is expected to reduce walls' construction costs, adding the reduction of labor time and of the waste generated, reducing the overall ecological footprint.

It is also foreseen increasing the use of cork products in combination with other materials for structural purposes, as well as uses of very high value (functional materials) such as innovative new applications in the construction industry and other specific fields. As an example, it can also be foreseen the use of agglomerated cork as component material in sandwich structures (Soares, 2007; Silva et al., 2010). Hybrid sandwich panels with a new corkbased plastic composite material as core material were investigated and compared with other materials proving that the new core cork-based material is competitive (Kim, 2011).

In this field can be further highlighted new products previously studied but not yet in the market, such as corkboards with ligands based on lignin residues (Gil, 2007a); products obtained with mixtures of mortar, plaster, and other materials with cork; cork composites with pulp and various natural fibers combined (Fernandes et al., 2009); cork waste-polymer composites (Fernandes et al., 2011); and still different textiles using cork.

It is also under development an ecoefficient partition wall. This material uses by-products of other industrial productions such as gypsum from the desulfurization of flue gases from power plants and textile fibers from the recycling of old tires, together with the expanded cork regranulate. The composite material can be used in partitions or walls in new buildings rehabilitation.

A new patented composite of cork and beverage cartons was developed. The process aimed at the utilization of packing materials as cork stoppers and multilayer (card, aluminum, polyethylene) packages. These packing materials are ground, mixed, and hot pressed, using operational conditions, which allow the thermoplastic and cork composition materials to act as binding agents. A wide range of physical and mechanical characteristics was obtained depending on the cork:beverage carton ratio and on the temperature and pressure conditions, among other parameters (Gil and Silva, 2005).

There are also plans to use some structural building elements made of cork and the use of "three-dimensional" pieces (irregular shapes, reliefs). The aim is to contribute to a greater architectural value, in particular, through the use of CAD/CAM technologies (especially at the end of their production chain), which allows a great geometric freedom and customization possibilities, as can be seen in SOFALCA homepage [http:// sofalca.pt/corkwave/index.html (accessed on 2014.12.15)].

Different cork layered plywood composites (plywood board + cork core) and plywood board with cork core and cork face layers were produced, tested, and compared with standard particle boards and plywood boards. The cork layered plywood showed some better characteristics in comparison with these marketed products (Král et al., 2014).

Reference is also done to new composites based on cork powder and reinforced with carbon nanotubes (Daveiga and Ferreira, 2005), which are anticipated with high tensile strength and ductility, foreseeing applications such as acoustic and thermal insulation construction materials. A new composite has also just being divulged [see link http://webcache. googleusercontent.com/search?q=cache: AU635p1xh24J:www.greenfibertech.com/ file_bank/Materia_Brochura.pdf $+\& c d=2 \&$ $\mathrm{hl}=\mathrm{pt}-\mathrm{PT} \& \mathrm{ct}=\mathrm{clnk} \& \mathrm{gl}=\mathrm{pt} \quad($ accessed on 2014.12.15)] based on plastic, wood fibers, and cork (a kind of plastic timber) for different applications including building.

It should be noted here too the possibility of future use of paints incorporating cork particles. These particles can have different particle sizes and different proportions, resulting in a lower thermal conductivity and a higher acoustic absorption compared with standard paints, thus contributing to a better housing (Gil and Marreiros, 2011a).

Cork agglomerates and cork rubber composites can be a solution to provide damping capacity also including low weight and thermal and acoustic insulation (Policarpo et al., 2013).

In some recent meetings of relatively narrow scope was also released information on projects and studies in which new products are being developed based on the projected cork and cork products with fiberglass, resin, and cork and even combining ceramic and cork.

Concluding here were described some aspects related to sustainability and the contribution of new products based on cork to this concept, prefiguring an interesting future in this field. Cork, which is a material that comes from the past, is walking to the future.

\section{REFERENCES}

Branco, F. G., Reis, M. L. B. C., and Tadeu, A. (2008). Experimental evaluation of the durability of cork concrete. Int J Hous Sci 32, 149-162.

Daveiga, J., and Ferreira, P. (2005). "Smart and nano materials in architecture," in Conference ACADIA 05: Smart Architecture (Savannah: SCAD), 58-67.

Esteves, D. (2010). Desenvolvimento, caracterização e avaliação do comportamento termomecânico de um novo material constituído principalmente por cortiça. MSc. thesis, Lisbon: Instituto Superior Técnico.

Fernandes, E. M., Corelo, V. M., Chagas, J. A. M., Mano, J. F., and Reis, R. L. (2009). Compósitos à base de cortiça reforçados com fibras. Portuguese patent PT 104704.

Fernandes, E. M., Corelo, V. M., Chagas, J. A. M., Mano, J. F., and Reis, R. L. (2011). Properties of new corkpolymer composites: advantages and drawbacks as compared with commercially available fibreboard materials. Compos Struct 93, 3120-3129.

Gil, L. (1998). Cortiça - Produção, Tecnologia e Aplicação. Lisboa: INETI.

Gil, L. (2007). Cork as a Building Material. Technical Manual. Santa Maria de Lamas: APCOR.

Gil, L. (2007a). "New cork agglomerates based on modified lignin ecobinders," in 15th European Biomass Conference \& Exhibition (Berlin).

Gil, L. (2011). Environmental, sustainability and ecological aspects of cork products for building. Sci Technol Mater 23, 87-90.

Gil, L. (2014). Cork: a strategic material. Front Chem 2:16. doi:10.3389/fchem.2014.00016

Gil, L., and Marreiros, N. (2011a). Tintas com incorporação de partículas de cortiça para melhor comportamento térmico e acústico. Sci Technol Mater 23, 15-17.

Gil, L., and Silva, P. (2005). Processo para a produção de aglomerados compósitos e produtos obtidos pelo processo. Portuguese patent PT 102992.

Kim, S. (2011). A Study on Cork-Based Plastic Composite Material, Thesis for Engineer's Degree, Massachusetts Institute of Technology, Cambridge.

Král, P., Klémek, P., Mishra, P. K., Rademacher, P., and Wimmer, R. (2014). Preparation and characterization of cork layered composite plywood boards. Bioresources 9, 1977-1985. doi:10.15376/biores.9.2. 1977- 1985

Pereira, H. (2007). Cork: Biology, Production and Uses. Amesterdam: Elsevier.

Policarpo, H., Diogo, A. C., Neves, M. M., and Maia, N. M. M. (2013). "A note on the estimation of cork composite elasto-dynamic properties and their frequency dependence," in ICEDyn 
2013 - International Conference on Structural Engineering Dynamics (Sesimbra: Hindowi Publishing Corporation).

Silva, J. M., Devezas, T., Silva, A., Gil, L., Nunes, C., and Franco, N. (2010). Exploring the use of cork based composites for aerospace applications. Mater Sci Forum 636-637, 260-265. doi:10.4028/www. scientific.net/MSF.636-637.260

Soares, B. (2007). Estruturas sandwich com utilização de núcleos de cortiça. MSc. thesis, Instituto Superior Técnico, Lisbon.
Conflict of Interest Statement: The author declares that the research was conducted in the absence of any commercial or financial relationships that could be construed as a potential conflict of interest.

Received: 20 November 2014; accepted: 29 December 2014; published online: 19 January 2015.

Citation: Gil L (2015) Cork: sustainability and new applications. Front. Mater. 1:38. doi: 10.3389/fmats.2014.00038
This article was submitted to Polymer Chemistry, a section of the journal Frontiers in Materials.

Copyright (๑) 2015 Gil. This is an open-access article distributed under the terms of the Creative Commons Attribution License (CC BY). The use, distribution or reproduction in other forums is permitted, provided the original author(s) or licensor are credited and that the original publication in this journal is cited, in accordance with accepted academic practice. No use, distribution or reproduction is permitted which does not comply with these terms. 